University of Warwick institutional repository: http://go.warwick.ac.uk/wrap This paper is made available online in accordance with publisher policies. Please scroll down to view the document itself. Please refer to the repository record for this item and our policy information available from the repository home page for further information.

To see the final version of this paper please visit the publisher's website. Access to the published version may require a subscription.

Author(s): Jonathan Gardner and Andrew J. Oswald

Article Title: Do divorcing couples become happier by breaking up?

Year of publication: 2006

Link to published version: http://dx.doi.org/ 10.1111/j.1467-

985X.2006.00403.x

Publisher statement: The definitive version is available at www.blackwell-synergy.com 


\section{Do Divorcing Couples Become Happier By Breaking Up?}

October 2005

Forthcoming in the Journal of the Royal Statistical Society

Dr. Jonathan Gardner and Professor Andrew J. Oswald

Watson Wyatt Worldwide and Department of Economics, University of Warwick, UK

Summary. Divorce is a leap in the dark. This paper investigates whether people who split up actually become happier. Using the British Household Panel Survey, we are able to observe an individual's level of psychological wellbeing in the years before and after divorce. Our results show that divorcing couples reap psychological gains from the dissolution of their marriages. Men and women benefit equally. The paper also studies the effects of bereavement, of having dependent children, and of remarriage. We measure wellbeing using GHQ and life-satisfaction scores.

JEL codes: J12, I3

Keywords: Divorce; Happiness; GHQ; Life satisfaction; Longitudinal data

\section{Introduction}

It is known from cross-sectional studies (Argyle 1989, Oswald 1997, Waite and Gallagher 2000) that reported happiness is greater among married people than among the divorced. Yet this is not a persuasive reason to believe that divorce reduces wellbeing. Because their causal implications are hard to interpret, cross-section patterns can only be suggestive. Indeed, one approach would be to argue that divorce must make people happier, because the decision to end a marriage will only be made where the (perceived) benefits of doing so outweigh the costs. 
The choice to dissolve a marriage, however, is a rare decision for an individual. It is also made under extreme uncertainty. Moreover, there is evidence that human beings are sometimes bad at 'affective' forecasting, namely, at predicting how happy they will be after they take an action (see, for example, Gilbert et al 1998). Thus prospective divorcees could be mistaken about how they will feel ex post. In addition, divorce need not reflect a voluntary decision by both partners. A natural research question, therefore, is whether couples actually become happier by splitting up. We provide evidence that they do.

To make persuasive empirical progress on this problem, data with special features are required. First, to measure the psychic costs or benefits of divorce, a measure of psychological wellbeing must be available. Second, it is necessary to have a panel of people, that is, longitudinal rather than purely cross-sectional information, so as to observe couples both before their marriages founder and after divorce. This allows us to factor out people's innate dispositions (or 'fixed effects'). Using information from the British Household Panel Survey, we construct one of the first longitudinal tests.

Marital breakdown is now common. In Britain there are approximately 160,000 divorces a year. At the start of the 1960 s, the figure was 30,000 . Thanks to recent work such as Kiernan and Mueller (1998), Ermisch and Francesconi (2000), Böheim and Ermisch (2001) and Chan and Halpin (2001), much is known about the characteristics of those in Great Britain who divorce. The emotional effects, however, are less well understood.

A recent paper that uses data through time to examine the relationship between marriage and wellbeing is that of Clark et al (2003). The authors use a German panel to examine the impact of marriage and widowhood (where the word 'widowhood' 
here and later is meant generically, namely, to encompass also male widower-hood) upon subjective wellbeing levels. Marriage is found to generate an upward shock to life satisfaction levels, but this effect is predominantly in the years immediately before or after marriage. On average, five years after marriage, satisfaction levels have returned close to their 'baseline' level. Widowhood exerts a negative effect upon life satisfaction, and one that dissipates only very slowly over time. After eight years the widowed still have lower wellbeing than the continuously married. Clark et al (2004) analyses the consequences of various life events, including divorce, upon life satisfaction, and finds quite complicated lead and lag effects, and that women seem to be more affected than men by marriage and divorce.

Some previous studies on longitudinal US data have attempted to examine the relationship between subjective wellbeing levels and divorce. Hetherington and Kelly (2002) provide an overview. Booth and Amato (1991) analyse the relation between divorce and distress, using a three wave American panel, where individuals are sampled in 1980, 1983 and 1988. They model distress as a function of the time to divorce, and the years since divorce, using recall data from the divorce date. The authors find that stress levels are high close to the divorce date, but subsequently decline as time passes. Pevalin and Ermisch (2004) explore what mental health does to the probability of divorce, rather than what shapes mental wellbeing. Sun (2001), Sun and Yi (2002) and Videon (2002) study young people's reactions to parental divorce. Amato (2000) and Wang and Amato (2000) examine the role of individuals' attitudes in predicting who will recover most fully from divorce. Johnson and $\mathrm{Wu}$ (2002) study the same U.S. data as Booth and Amato (1991), but with an additional wave, 1992, and a different statistical method. They conclude that it is only those divorcees who remarry who psychologically recover. These studies are, however, 
hampered by the small number of measurement occasions, by the relatively long time spans between observations, and the fact that wellbeing cannot be measured at set time intervals from the date of divorce.

After the first draft of this paper was written, the work of Wade and Pevalin (2004) was published. It also uses the British Household Panel, and there is some overlap with our analysis (particularly their Figure 1), but Wade and Pevalin are not concerned with whether, in the long term, people gain from divorce, and they present no tests of statistical significance on that issue. Their focus is on the psychological characteristics of those who divorce and on the immediate impact upon mental stress.

The following sections use wellbeing data to examine whether couples who split up go on to reap psychological benefits. In a society where divorce is common, this issue seems an important one. Section two provides an overview of the patterns in psychological wellbeing data; section three describes the data and the mental health questions analysed; section four reports the empirical evidence. Section five concludes.

\section{Subjective measures of wellbeing}

One definition of happiness is the degree to which an individual judges the overall quality of life in a favourable way (Veenhoven, 1991, 1993). Self-reported wellbeing measures are thought to be a reflection of at least four factors: objective circumstances, aspirations or expectations, comparisons with others, and a person's baseline happiness or disposition (e.g. Warr, 1980, Chen and Spector, 1991). Frey and Stutzer (2002) describes evidence that recorded happiness levels have been demonstrated to be correlated with:

1. Objective characteristics such as unemployment. 
2. The person's recall of positive versus negative life-events.

3. Assessments of the person's happiness by friends and family members.

4. Assessments of the person's happiness by his or her spouse.

5. Authentic or so-called Duchenne smiles (a Duchenne smile occurs, technically speaking, when the zygomatic major and obicularus orus facial muscles both fire, and human beings identify these as 'genuine' smiles).

6. Heart rate and blood pressure measures of responses to stress.

7. Skin-resistance measures of response to stress.

8. Electroencephelogram measures of prefrontal brain activity.

Rather than summarise the psychological literature's assessment of wellbeing data, this paper refers readers to the checks on self-reported happiness statistics that are discussed in Argyle (1989) and Myers (1993), and to psychologists' articles on reliability and validity, such as Fordyce (1985), Larsen, Diener, and Emmons (1984), Pavot and Diener (1993), and Watson and Clark (1991). See also the valuable recent analysis of Shields and Price (2005).

We assume a reported wellbeing function:

$$
\mathrm{r}=\mathrm{h}(\mathrm{u}(\mathrm{y}, \mathrm{z}, \mathrm{m}, \mathrm{t}))+\mathrm{e}
$$

where $\mathrm{r}$ is some measure of psychological stress or self-reported wellbeing; $\mathrm{u}(\ldots)$ is to be thought of as the person's true wellbeing; $h($.$) is a non-differentiable function$ relating actual to reported wellbeing; $\mathrm{y}$ is income; $\mathrm{z}$ is a set of demographic and personal characteristics; $\mathrm{m}$ is marital status; $\mathrm{t}$ is the time period; and e an error term. It is assumed that $\mathrm{u}(\ldots$.$) is a function that is observable only to the individual. Its$ structure cannot be conveyed unambiguously to the interviewer or any other individual. The error term, e, then subsumes among other factors the inability of 
human beings to communicate accurately their happiness level (your 'two' may be my 'three'). The measurement error in reported wellbeing data would be less easily handled if wellbeing were to be used as an independent variable. This approach might be viewed as an empirical cousin of the experienced-utility idea advocated by Kahneman et al (1997).

It is possible to view some of the self-reported wellbeing questions in the psychology literature as assessments of a person's lifetime or expected stock value of future utilities. Equation 1 would then be rewritten as an integral over the $u(\ldots)$ terms. This paper, however, will use stress questions on the assumption they describe a flow rather than a stock, and as such are akin to approximations of instantaneous wellbeing.

\section{Data}

The data used in this study come from the first eleven waves of the British Household Panel Survey (BHPS). This is a nationally representative sample of more than 5,000 British households, containing over 10,000 adult individuals, conducted between September and Christmas of each year from 1991 (see Taylor et al, 2002). Respondents are interviewed in successive waves; households who move to a new residence are interviewed at their new location; if an individual splits off from the original household, all adult members of their new household are also interviewed. Children are interviewed once aged 16. The sample has remained broadly representative of the British population throughout the 1990s (see Nathan, 1999).

To examine how wellbeing changes over time, in response to marital dissolution, one would ideally know the date at which individuals felt their marriage ended, as opposed to the legal date of divorce. The approach taken in the paper is thus to define 'divorce' (marital termination) as being either a legal divorce or a 
marital separation. Our data record formal marital breakdown; they do not cover the dissolution of cohabiting relationships. The people we study were legally married in 1991, namely, at the beginning of the BHPS survey period. A more detailed description of variable definitions can be found in the appendix. Our definition follows referees' suggestions. An earlier version of the paper used a different definition of divorce -- where separations were counted only if they had lasted at least one full year -- but the results of the analysis were broadly similar. In our data, approximately two thirds of the marital breakdowns are legal divorces and one third are separations.

In this way, the BHPS provides a sample of some 430 cases where we observe a transition from marriage into 'divorce' (where, for simplicity, we later drop the inverted commas). Given the high rate of marital failure in Great Britain, this number may, at first sight, appear small. However, we focus upon flow transitions into divorce for the initial stock of married individuals, and ignore pre-existing cases of divorce. Moreover, we sample all married persons, rather than newlyweds, and so observe marriages which may have already survived for some time, and from which exit rates are lower.

The divorce numbers through the years are given in Table 1. The table also documents 278 marital transitions caused by death of a partner. Later in the paper we contrast the effects on wellbeing of divorced transitions compared with widowed transitions.

The BHPS contains a standard mental wellbeing measure, a General Health Questionnaire (GHQ) score. This is widely used by medical researchers and psychiatrists as an indicator of strain or psychological distress. It is less familiar to social scientists, but the GHQ is probably the most widely used, questionnaire-based, 
method of measuring mental stress. In the spirit favoured by psychologists, it amalgamates answers to the following list of twelve questions, each of which is, itself, scored on a four-point scale from 0 to 3 :

Have you recently:

1. Been able to concentrate on whatever you are doing?

2. Lost much sleep over worry?

3. Felt that you are playing a useful part in things?

4. Felt capable of making decisions about things?

5. Felt constantly under strain?

6. Felt you could not overcome your difficulties?

7. Been able to enjoy your normal day-to-day activities?

8. Been able to face up to your problems?

9. Been feeling unhappy and depressed?

10. Been losing confidence in yourself?

11. Been thinking of yourself as a worthless person?

12. Been feeling reasonably happy all things considered?

We use the responses to these so-called GHQ-12 questions. For our measure of mental wellbeing, we take the simple sum of the responses to the twelve questions, coded so that the response with the lowest wellbeing value scores 3 and that with the highest wellbeing value scores 0 . This approach is sometimes called a Likert scale and is scored out of 36. This GHQ measure of mental distress, or lack of wellbeing, thus runs from a worst possible outcome of 36 (all twelve responses indicating very poor psychological health) to a minimum of 0 (no responses indicating poor 
psychological health), where people here assess themselves relative to 'usual'. In general, medical opinion is that healthy individuals will score typically around 10-13 on the test. Numbers near 36 are rare and indicate depression in a clinical sense.

It is possible, of course, to object to GHQ as a measure of mental wellbeing. At the end of the paper, we briefly report, as a check, an equivalent exercise with lifesatisfaction data.

\section{Results}

\section{Estimation strategy}

The empirical approach is to estimate a version of equation 1. Wellbeing is assumed to be a function of the marital relationship, family income, personal characteristics (such as age, education, gender, race, and labour force status) and the time period. The wellbeing equation, for individual $\mathrm{i}$ in time period $\mathrm{t}$, is then expressed as:

$$
\begin{array}{r}
\mathrm{r}_{\mathrm{it}}=\mathrm{m}_{\mathrm{it}}^{\prime} \beta+\mathrm{y}_{\mathrm{it}}^{\prime} \delta+\mathrm{z}_{\mathrm{it}}^{\prime} \gamma+\varepsilon_{\mathrm{it}} \quad \mathrm{i}=1,2, \ldots, \mathrm{n}, \\
\mathrm{t}=1,2, \ldots, \mathrm{T},
\end{array}
$$

where $\mathrm{r}$ is the overall GHQ score (on a 0 to 36 scale), m represents marital status, $\mathrm{y}$ is family income, $\mathrm{z}$ a vector of individual characteristics and time dummies, $\varepsilon$ is the conformable error term with mean zero and constant variance, and $\beta, \delta$ and $\gamma$ the parameters to be estimated. Equations are estimated by OLS, both for the pooled sample and for males and females separately. This implicitly assumes responses are cardinal. If ordered probit or similar methods are used for the cross-section models, estimates are similar. These are available upon request.

Alternative specifications include controls for person-specific unobservable fixed effects $\left(\alpha_{\mathrm{i}}\right)$. These remove the influence of a person's innate disposition upon wellbeing scores, and capture all unobserved individual-specific heterogeneity in the wellbeing data that remains constant over time. The error term is then expressed: 


$$
\varepsilon_{\text {it }}=\alpha_{\mathrm{i}}+v_{\mathrm{it}}
$$

where $v_{\text {it }}$ is a random error term, and the equation to be estimated is then:

$$
\mathrm{r}_{\mathrm{it}}=\mathrm{m}_{\mathrm{it}}^{\prime} \beta+\mathrm{y}_{\mathrm{it}}^{\prime} \delta+\mathrm{z}_{\mathrm{it}}^{\prime} \gamma+\alpha_{\mathrm{i}}+\mathrm{v}_{\mathrm{it}}
$$

This can be estimated either by examining within-person deviations from means, or by examining changes over time (which allows the fixed effect to be correlated with observed characteristics), and inference is then driven by time-varying characteristics. Chapter 10 of Wooldridge (2002) contains a useful discussion of within-group and time-difference fixed effects estimators. Earlier versions of our paper included such estimates and these are available upon request.

\section{Cross-section estimates}

If we look first at simple equations, divorce in Great Britain appears to be harmful to psychological wellbeing. This is the conventional finding (see, for instance, the GHQ equations in Clark and Oswald 1994, or the recent results of Wade and Pevalin 2004). Table 2 provides a number of mental-strain regression equations for the BHPS sample pooled from the start of the 1990s up to 2001.

Married people have much lower levels of mental strain than others in the sample. In column 1 of Table 2 , the marriage dummy variable enters with a coefficient of -1.274 and is statistically significantly different from zero at approximately the 0.1 percent level. Attention is restricted here to individuals who were married at the beginning of the British Household Panel period of data collection and for whom marital status is known in each of the waves they are interviewed. By focusing on the individuals initially married, we may observe a somewhat larger marital effect upon wellbeing than in estimates from a cross-section of the entire population. There are two reasons. First, we exclude those who are single (unmarried) whose mental strain levels are, on average, greater than those of married 
persons but lower than the divorced or separated. Second, divorces in our sample are likely to be relatively recent. If any psychological harm associated with divorce dissipates over time, our sample of divorcees will show greater GHQ strain scores than the population of divorcees.

The omitted or base group, in the first column of Table 2, combines separated and legally divorced people. The coefficient estimate on marriage is large as well as well-determined. The standard deviation of GHQ scores is approximately 5, and the largest single effect here on GHQ wellbeing is from unemployment, at $1.889 \mathrm{GHQ}$ points. Hence a marriage coefficient of approximately 1.3 points indicates that the positive effect of marriage on wellbeing is equal, in absolute value, to approximately two thirds of the size of the negative effect of being unemployed.

The second column of Table 2 shows that divorcees have high mental strain, or, in other words, low psychological wellbeing. The coefficient on divorce is 1.115 , which implies a strong negative effect, and has a standard error below 0.3. As explained, a 'divorce' is here categorized as legal divorce or marital separation.

A separate variable is included in column 2 of Table 2 for being a widow or widower. Its coefficient is a little larger, at 1.492, than that on divorce. The omitted category in this second column of Table 2 is those married.

Table 2 also divides the data into male and female sub-samples. In Table 2, the divorce coefficient for males is 1.062 in the fourth column, and 1.055 for females in the sixth column. It is not possible to reject the null of equality of these. To put this in a slightly different way, men and women seem, in cross-section, to reap approximately the same psychological wellbeing benefits from a lasting marriage. In columns 3 and 5 of Table 2, the marriage coefficients in male and female mental strain equation are -1.006 and -1.339 , respectively. 
The remaining coefficients in Table 2 follow the traditional pattern of mental wellbeing equations. Higher income is associated with better psychological health. There are non-linear effects from age; mental strain peaks around, approximately, the age of 40. Unemployment is associated with a substantial psychological loss. Race and gender both have statistically significant effects on GHQ scores. Finally, educational qualifications and out-of-the-labour-force status matter (the latter possibly because, especially for males, it is associated with incapacity and ill-health). The same kind of results can be seen, in different data sets, for the United Kingdom and the USA in Blanchflower and Oswald (2004).

The thrust of Table 2 is that divorce is apparently bad for people. On closer examination, however, such a conclusion turns out to be, at best, incomplete.

\section{A Graphical Approach to Longitudinal Estimates}

Because the BHPS is an annual panel, it is possible to follow individuals in a detailed way through time. People's wellbeing can be measured before and after major life events such as divorce. When this is done, a different picture emerges.

Table 3 examines people's GHQ mental stress scores year-by-year. The Table records the mean levels of mental strain for various groups: it splits the sample into those who go on to divorce, those who go on to be widowed, and those who remain married. Five years of numbers are reported. The purpose is to understand the run-up to, and aftermath from, divorce. As a comparison, bereavement is also studied. This form of longitudinal test goes some way to circumvent the causality problem identified by Frey and Stutzer (2004).

Define $\mathrm{T}$ as the time point when a life event occurs. Mean GHQ scores are given in the first column of Table 3 -- for the sample of people who go on to break up from their partners -- for each of the two years before the divorce and each of the two 
years after divorce. In a sense, people's unchanging personal characteristics are thereby differenced out.

What Table 3 shows is that average mental strain increases through time periods T-2 and T-1 in the run-up to the divorce. There is a spike in the data. Psychological strain reaches a maximum in the year of divorce itself. It then falls over the ensuing years of $\mathrm{T}+1$ and $\mathrm{T}+2$.

Following a method suggested by Clark et al (2003), the path of mental wellbeing can usefully be represented by a simple time-series graph of the kind portrayed in Figure 1. Three groups' mean GHQ scores are depicted. The solid black line depicts the strain levels of those who are going to divorce. It rises nearly 2 GHQ points (from 12.98 to 14.85 ) and then falls strongly to 11.98 by $\mathrm{T}+2$. Over the five years, therefore, Figure 1 provides evidence of a gain to a person from splitting up from their spouse: there is a decline in mental strain of one GHQ point. By this criterion, divorce seems to work.

There are two natural comparison groups, and they are depicted in Figure 1.

First, Figure 1 plots data on people who are widowed. This is the dotted line that begins at a GHQ score of approximately 11.69 and increases rapidly to, in period $\mathrm{T}$, a maximum of approximately 17.20. As might be expected, bereavement induces very considerable mental strain in the partner who remains alive. Recovery among those widowed, however, means that by $\mathrm{T}+2$ (that is, by two years later) the GHQ score among the bereaved group stands slightly below that of divorcees, and approximately equal to where the bereaved were two years prior to the spouse's death.

Second, Figure 1 includes a plot of the mental strain levels of those married people whose partnerships continue. This is the smooth lower dotted line that rises only slightly between $\mathrm{T}-2$ and $\mathrm{T}+2$, from a value of 10.92 to one of 11.09 . 
Table 4 reports means and associated standard errors. As background, it is useful to note that those who remain married between $\mathrm{T}-1$ and $\mathrm{T}$ have, on average, a small but statistically significant increase in mental strain (a change of 0.113 with a standard error of 0.026). The numbers in Table 4 are based on the same data as Table 3, but differ very slightly. This is because they are use very slightly different samples. To calculate the change in a person's GHQ stress score between two years, a person must be observed in both years; therefore a person whose score is observed in only one of the years is deleted.

Those who divorce go on to reap noticeable psychological gains. Between T1 and $\mathrm{T}+1$, the middle of the first column of Table 4 demonstrates that the GHQ score of people who divorce improves on average by 1.965 points. The standard error on this number is 0.422 . When compared with the group who remain married, the improvement in wellbeing is 2.136 points (with a standard error of 0.423 ). This covers a span of three years. What about over a longer period? Again the first column of Table 4 provides an answer. Between $\mathrm{T}-2$ and $\mathrm{T}+2$, the relative improvement in wellbeing is 0.974 GHQ points (with a standard error of 0.451). Therefore, over a span of five years, divorce reduces mental strain by approximately one point on a General Health Questionnaire scale.

Those in the widowed group are different. The second column of Table 4 provides the key numbers. In the first year, widows and widowers suffer enormously, by almost 5 GHQ points on average. Bereaved partners experience increased stress also between $\mathrm{T}-1$ and $\mathrm{T}+1$, by 0.826 points, although the rise is not statistically significant at the 5\% level when compared with those individuals who remain married. Between $\mathrm{T}-2$ and $\mathrm{T}+2$, people who were married and become widowed 
actually show a slight improvement in mental wellbeing, of 0.183 points, although the change is not statistically well-determined.

Some people go on to remarry fairly quickly after a divorce. Therefore a natural research question is: how does their mental wellbeing compare with that of the divorcees who stay single? The answer seems to be that quickly remarrying (between $\mathrm{T}$ and $\mathrm{T}+2$ ) apparently does not make a substantial difference to wellbeing. Figure 2 provides the time paths of GHQ stress scores for each group. It can be seen, interestingly, that the starting and ending levels of mental wellbeing are approximately the same. So remarriage, by that criterion, makes no difference (though our instinct is that this result may not be robust to larger samples, and needs to be explored in future work). Nevertheless, the transition path for the singletons, shown as a solid line in Figure 2, reveals that they do seem to endure higher levels of stress in the intervening three years.

Table 5 gives more detailed information. Between $\mathrm{T}-1$ and $\mathrm{T}+1$, the improvement in mental strain is 2.093 for those who divorce and remain single, and 1.756 for those who divorce and quickly remarry. As the third column of Table 5 shows, the difference between these is not statistically significant. Over the longer period, perhaps of particular note, comparing the foot of the first column of Table 5 to the foot of the second column of Table 5, is the similar rate of recovery in GHQ scores for those who divorce and remain single (1.284 points between $\mathrm{T}-2$ and $\mathrm{T}+2)$ and those who divorce and remarry (1.124 points between $\mathrm{T}-2$ and $\mathrm{T}+2)$. In each case here, the figure is reported as a difference against couples who remain married.

Do men and women differ in how they recover from divorce and widowhood? The answer seems to be approximately no. 
Figures 3 and 4 look at mental strain levels for men and women separately. Here there is the same approximate shape -- rising and then falling -- over time both for the males and females. This seems important, because, in non-technical and media discussions of marital breakdown, the claim is sometimes heard that women suffer disproportionately in divorce.

In Figure 3 the $T=0$ spike in mental strain at divorce is actually sharpest for men, and the starting and ending GHQ scores are higher for women. However, each gender group ends, after divorce, with improved mental strain scores, by approximately one full GHQ point, in period $\mathrm{T}+2$. It is not possible, at the $5 \%$ significance level, to reject the null hypothesis that the change in GHQ (either up for the first span of two years, or down for the second span of two years) is the same for males and females. Men and women thus look broadly alike. Table 6 sets out the means for various time periods, but again men and women do not differ in a statistically significant way. Our findings are, of course, for mental wellbeing rather than financial circumstances, and, as a referee has pointed out, women may be more adversely affected than men in economic terms. It is conceivable that future research will find that men and women differ more fundamentally than this paper's finding suggests, but it is apparently not possible, within this data set, to say anything more definite about gender differences.

The impact of bereavement upon the remaining male or female spouse is studied in Figure 4. It can be seen that the increase in mental strain is severe for both groups. From year T-2 to the death of the partner at year T, the mean stress score of females increases by approximately $6 \mathrm{GHQ}$ points, while for males the increase is slightly below 5 GHQ points. A marked recovery in psychological wellbeing is then observed for each sex. The argument that the death of a spouse and divorce are 
empirically similar kinds of life events has been made before in the wellbeing literature - for example by Easterlin (2003).

A potentially important issue is how the presence of dependent children in a household affects the divorcing parents. This is explored in Figure 5. It can be seen that the spike in the mean GHQ stress score, reaching a level of 15.22, is somewhat greater for those with children. However, establishing that there are statistically significant differences is not straightforward. In our data set, for people whom we observe in each of the years, there are 223 divorcing individuals with children and 124 without. It can be seen, in the middle of the first two columns of Table 7, that the improvement in GHQ stress scores between year $\mathrm{T}-1$ and year $\mathrm{T}+1$ is 1.865 points for those with dependent children and 2.145 for the childless. The difference between these is just 0.280 , with a standard error of 0.857 .

If the longer period of $\mathrm{T}-2$ to $\mathrm{T}+2$ is considered, the improvement in GHQ from divorce is noticeably less among those people in the sample who have children. The third column of Table 7 reveals that the difference in the groups' wellbeing is 1.476. Nevertheless, the standard error is only 0.943 , so, although sample size admittedly becomes small, this difference is still not statistically significant at the $5 \%$ level.

Another question of interest is what happens to wellbeing levels inside a marriage. Figure 6 examines this issue. It takes data on 147 marital pairs who divorce. The Figure then plots the mean difference in the GHQ scores for the divorcing couple: (GHQ score for the wife minus GHQ score for the husband). Two years before divorce, wives are more stressed than their husbands, by 1.26 points. In the year of divorce, this reverses. Husbands become more stressed, by 0.67 points, than their wives. Two years after divorce, the early difference in mental wellbeing 
has approximately returned. Figure 6 shows that wives by year $\mathrm{T}+2$ are, on average, again more stressed than their husbands, by 1.39 points. It should perhaps be borne in mind that in a random cross-section of the British population the female GHQ scores are typically one or two points above the male scores. In this sense, the data are returning to their conventional levels.

As divorce apparently produces a large psychological improvement, does this imply that many married couples in Britain make a mistake by staying together? It does not. Those who choose to split up are not, of course, a random sample of the population. These couples are likely to be those with less happy marriages in the first place (and Figure 1 provides some evidence consistent with that, at year T-2, where the GHQ scores of those who will go on to divorce are two points above those who will remain married).

\section{$\underline{\text { A Check using Life Satisfaction Scores }}$}

As a final test, Table 8 moves to life satisfaction data. Correspondingly, Figure 7 is the equivalent to the earlier GHQ-based Figure 1.

The BHPS provides life satisfaction scores, on a one-to-seven points scale, for 1996-2000. In Table 8, although the numbers of observations are necessarily rather lower than for Table 4, it can be seen that the broad findings from this exercise are similar to the previous ones on GHQ strain. For example, there is an improvement in mental wellbeing between time $\mathrm{T}-1$ to $\mathrm{T}+1$ of 0.543 life-satisfaction points. The standard error on this number is 0.160 , so the null of zero can be rejected at normal confidence levels. In the case of life satisfaction, in fact, the improvement in wellbeing between $\mathrm{T}-1$ and $\mathrm{T}$ is itself positive and statistically significant, which is slightly earlier than in GHQ data. Relatively little can be said, however, about life satisfaction over the longer period of $\mathrm{T}-2$ to $\mathrm{T}+2$. The number of observations is only 
42 ; the measured rise in mental wellbeing compared to those continually married is positive but small.

Figure 7 illustrates, once again, that the widowed have recovered almost completely by two years after their bereavement. Married individuals have the highest measured levels of life satisfaction, although, as illustrated in Table 8 by the $\mathrm{T}-2$ to $\mathrm{T}+2$ change of -0.121 , there is, as in Table 4 , an underlying negative time-trend in mental wellbeing.

\section{Conclusions}

This study finds that divorce works. The longitudinal evidence in the paper suggests that marital dissolution eventually produces a rise in psychological wellbeing. Both men and women gain, and do so approximately equally. For those couples who take it, the leap into the dark seems to improve their lives.

As shown in Table 3, and elsewhere in the paper, divorce is traumatic in the short run. Yet, comparing two years before marital breakdown with two years afterwards, it is associated with an improvement of approximately one point on a standard General Health Questionnaire measure of mental stress. Whether this psychological benefit from divorce should be viewed as large or small is a matter of judgment. It is one fifth of the size, in absolute value, of the immediate impact effect upon mental wellbeing of the death of a spouse (and that is, perhaps as might be expected, the worst life event that is detectable in standard data sets).

This paper's results do not mean that greater numbers of British couples should dissolve their unions. Consistent with common sense, the data demonstrate that the men and women who split up were initially more highly stressed than the norm in the married population. We interpret this to mean that less happy partnerships are the ones that tend to end. 
There are four other findings.

First, the time path of mental strain during a period of divorce is similar to, but less extreme than, that of bereaved spouses. However, widowed people return to approximately the same level of wellbeing as they were at two years before their spouse died. Second, in a psychological sense, men and women are on average affected equally by divorce. Third, and perhaps surprisingly, whether a person remarries quickly does not seem to influence that individual's wellbeing level two years after divorce. Nevertheless, those who go on to remarry do have slightly easier transitions around the year of divorce. Fourth, there is a little evidence that people with dependent children suffer more from marital breakdown. The size of this effect, however, is not significantly different from zero at conventional confidence levels. 


\section{Acknowledgements}

This paper is forthcoming in the Journal of the Royal Statistical Society: Series A.

For many valuable suggestions, we thank Richard Easterlin, Peter Lynn, Alois Stutzer and two referees. The Economic and Social Research Council (ESRC) provided research support. The usual disclaimer applies. In particular, the views in this paper are not those of Watson Wyatt. The British Household Panel Survey data were made available through the UK Data Archive. The data were originally collected by the ESRC Research Centre on Micro-social Change at the University of Essex, now incorporated within the Institute for Social and Economic Research. Neither the original collectors of the data nor the Archive bear any responsibility for the analyses or interpretations presented here. 


\section{Appendix: Definition of marital status and sample selection}

\section{Definition of marital status}

We define 'divorce' as either legal divorce or marital separation. In examining the psychological impact of marital breakdown, we would ideally know the date at which respondents felt their marriage had ended, as opposed to any formal end-date. The approach here attempts to approximate that.

Our divorce variable is, necessarily, only defined where it is possible to observe individuals for consecutive periods. We have to exclude cases where the individual is observed to have become divorced in a later wave, but, because his or her marital status is missing in intervening years, we do not know exactly when.

An individual is defined as always married if on each of the $\mathrm{N}$ waves when sampled they respond that they are married. We allow for non-response in marital status in a limited way. If an individual responds that they are married at year $\mathrm{t}-1$ and at year $t+1$, but marital status is missing in year $t$, we assume they are continually married over the three-year period. However, if marital status is missing for two or more consecutive years, marital status is treated as unknown for that period.

\section{Sample selection}

The paper restricts attention solely to individuals who are married in 1991, and examines how mental strain scores change over time for those individuals who become divorced relative to those who remain married. Respondents who become widowed are also studied. The sample is restricted to those observations with nonmissing values for the covariates. 


\section{References}

Amato, P.R. (2000) Consequences of divorce for adults and children. Journal of Marriage and the Family, 62,1269-1287.

Argyle, M. (1989) The Psychology of Happiness. London: Routledge.

Blanchflower, D.G. \& Oswald, A.J. (2004) Wellbeing over time in Britain and the USA, Journal of Public Economics, 88, 1359-1386.

Böheim, R. \& Ermisch, J. (2001) Partnership dissolution in the UK - the role of economic circumstances. Oxford Bulletin of Economics and Statistics, 63, 197208.

Booth, A. \& Amato, P. (1991) Divorce and psychological stress. Journal of Health and Social Behavior, 32, 396-407.

Chan, T. W. \& Halpin, B. (2001) Children and marital instability in the UK. Mimeo. Department of Sociology: University of Oxford.

Chen, P. Y. \& Spector, P. E. (1991) Negative affectivity as the underlying cause of correlations between stressors and strains. Journal of Applied Psychology, 7, 398-407.

Clark, A. E., Diener, E., Georgellis, Y. \& Lucas, R. E. (2003) Re-examining adaptation and the setpoint model of happiness: Reactions to changes in marital status. Journal of Personality and Social Psychology. 84 (3), 527-539.

Clark, A. E., Diener, E., Georgellis, Y. \& Lucas, R. E. (2004) Leads and lags in life satisfaction: A test of the baseline hypothesis. Mimeo. DELTA, Paris.

Clark, A.E. \& Oswald, A.J. (1994) Unhappiness and unemployment. Economic Journal, 104, 648-659.

Easterlin, R.A. (2003) Explaining happiness. Proceedings of the National Academy of Sciences, 100, 11176-11183.

Ermisch, J. \& Francesconi, M. (2000) Cohabitation in Great Britain: not for long, but here to stay. Journal of the Royal Statistical Society (Series A), 163, 153-171.

Fordyce, M. W. (1985) The psychap inventory: A multi-scale test to measure happiness and its concomitants. Social Indicators Research, 18, 1-33.

Frey, B. S. \& Stutzer, A. (2002) Happiness and Economics. Princeton, USA: Princeton University Press.

Frey, B.S. \& Stutzer, A. (2004) Does marriage make people happy, or do happy people get married? Working paper, University of Zurich.

Gardner, J. \& Oswald, A. (2004) How is mortality affected by money, marriage and stress? Journal of Health Economics, 23, 1181-1207.

Gilbert, D. T., Pinel, E. C., Wilson, T. D., Blumberg, S. J., \& Wheatley, T. (1998) Immune neglect: A source of durability bias in affective forecasting. Journal of Personality and Social Psychology, 75, 617-638.

Hetherington, E. M., \& John Kelly. (2002). For Better or Worse: Divorce Reconsidered. New York: W. W. Norton.

Johnson, D. R. \& Wu, J. (2002) An empirical test of crisis, social selection, and role explanations of the relationship between marital disruption and psychological distress: A pooled time-series analysis of four-wave panel data. Journal of Marriage and Family, 64, 211-224.

Kahneman, D., Wakker, P. P. \& Sarin, R. (1997) Back to Bentham? Explorations of experienced utility. Quarterly Journal of Economics, 112, 375-406.

Kiernan, K. \& Mueller, G. (1998) The divorced and who divorces? Working paper. London School of Economics: Centre for Analysis of Social Exclusion. 
Larsen, R. J., Diener, E. \& Emmons, R. A. (1984) An evaluation of subjective wellbeing measures. Social Indicators Research, 17, 1-18.

Myers, D. G. (1993) The Pursuit of Happiness. London: Aquarian.

Nathan, G. (1999) A review of sample attrition and representativeness in three longitudinal surveys. London: Office for National Statistics.

Oswald, A.J. (1997) Happiness and economic performance. Economic Journal, 107, 1815-1831.

Pavot, W. \& Diener, E. (1993) Review of the satisfaction with life scales. Psychological Assessment, 5, 164-172.

Pevalin, D.J. \& Ermisch, J. (2004) Cohabiting unions, repartnering and mental health. Psychological Medicine, 34(8), 1553-1559.

Shields, M.A. \& Price, S.W. (2005) Exploring the economic and social determinants of psychological wellbeing and perceived social support in England. Journal of the Royal Statistical Society(Series A), 168, 513-537.

Sun, Y. (2001) Family environment and adolescents' wellbeing before and after parents' marital disruption: A longitudinal analysis. Journal of Marriage and Family, 63, 697-713.

Sun, Y. \& Li, Y. (2002) Children's wellbeing during parents' marital disruption process: A pooled time-series analysis. Journal of Marriage and Family, 64, 472-488.

Taylor, M. F., Brice, J., Buck, N. \& Prentice-Lane, E. (2002) British Household Panel Survey User Manual. Colchester: University of Essex.

Veenhoven, R. (1991) Is happiness relative? Social Indicators Research, 24, 1-34.

Veenhoven, R. (1993) Happiness in Nations: Subjective Appreciation of Life in 56 Nations, 1946-1992. Rotterdam: Erasmus University Press.

Videon, T. M. (2002) The effects of parent-adolescent relationships and parental separation on adolescent wellbeing. Journal of Marriage and Family, 64, 489503.

Wade, T.J. \& Pevalin, D.J. (2004) Marital transitions and mental health. Journal of Health and Social Behavior, 45, 155-170.

Waite, L. \& Gallagher, M. (2000) The Case for Marriage. New York: Doubleday.

Wang, H. \& Amato, P.R. (2000) Predictors of divorce adjustment: stressors, resources, and definitions. Journal of Marriage and the Family, 62, 655-668.

Warr, P. B. (1980) The springs of action. In Models of Man. Leicester: British Psychological Society.

Watson, D. \& Clark, L. A. (1991) Self versus peer ratings of specific emotional traits: Evidence of convergent and discriminant validity. Journal of Personality and Social Psychology, 60, 927-940.

Wooldridge, J.M. (2002) Econometric Analysis of Cross Section and Panel Data. Cambridge, Mass: MIT Press. 
Table 1

Numbers of Divorces and Widowhoods in the Data

\begin{tabular}{|c|c|c|}
\hline Survey wave & $\frac{\text { Divorce }}{\text { transitions }}$ & $\frac{\text { Widowed }}{\text { transitions }}$ \\
\hline 1992 & 59 & 32 \\
\hline 1993 & 50 & 37 \\
\hline 1994 & 46 & 32 \\
\hline 1995 & 47 & 30 \\
\hline 1996 & 44 & 26 \\
\hline 1997 & 55 & 28 \\
\hline 1998 & 48 & 25 \\
\hline 1999 & 26 & 36 \\
\hline 2000 & 24 & 15 \\
\hline 2001 & 31 & 17 \\
\hline Total & 430 & 278 \\
\hline
\end{tabular}


Table 2

Mental Stress Equations

(GHO is the dependent variable)

\section{Ordinary-least-squares estimation 1991-2001}

\begin{tabular}{|c|c|c|c|c|c|c|}
\hline $\begin{array}{l}\text { REGRESSOR } \\
\text { Married }\end{array}$ & $\begin{array}{r}\text { POOLED } \\
-1.274 \\
(0.204)\end{array}$ & POOLED & $\begin{array}{l}\text { MALE } \\
-1.006 \\
(0.300)\end{array}$ & MALE & $\begin{array}{r}\text { FEMALE } \\
-1.339 \\
(0.273)\end{array}$ & FEMALE \\
\hline Divorced & & $\begin{array}{r}1.115 \\
(0.267)\end{array}$ & & $\begin{array}{r}1.062 \\
(0.367)\end{array}$ & & $\begin{array}{r}1.055 \\
(0.371)\end{array}$ \\
\hline Widowed & & $\begin{array}{r}1.492 \\
(0.294)\end{array}$ & & $\begin{array}{r}0.912 \\
(0.500)\end{array}$ & & $\begin{array}{r}1.662 \\
(0.369)\end{array}$ \\
\hline Log(family income) & $\begin{array}{l}-0.422 \\
(0.077)\end{array}$ & $\begin{array}{l}-0.423 \\
(0.077)\end{array}$ & $\begin{array}{l}-0.233 \\
(0.104)\end{array}$ & $\begin{array}{r}-0.233 \\
(0.104)\end{array}$ & $\begin{array}{l}-0.467 \\
(0.110)\end{array}$ & $\begin{array}{l}-0.475 \\
(0.110)\end{array}$ \\
\hline Age & $\begin{array}{r}0.740 \\
(0.105)\end{array}$ & $\begin{array}{r}0.736 \\
(0.106)\end{array}$ & $\begin{array}{r}0.943 \\
(0.147)\end{array}$ & $\begin{array}{r}0.945 \\
(0.147)\end{array}$ & $\begin{array}{r}0.588 \\
(0.150)\end{array}$ & $\begin{array}{r}0.584 \\
(0.151)\end{array}$ \\
\hline $\mathrm{Age}^{2} / 10$ & $\begin{array}{r}-0.143 \\
(0.020)\end{array}$ & $\begin{array}{r}-0.142 \\
(0.020)\end{array}$ & $\begin{array}{l}-0.181 \\
(0.028)\end{array}$ & $\begin{array}{r}-0.181 \\
(0.028)\end{array}$ & $\begin{array}{r}-0.120 \\
(0.030)\end{array}$ & $\begin{array}{l}-0.119 \\
(0.030)\end{array}$ \\
\hline $\mathrm{Age}^{3} / 1000$ & $\begin{array}{r}0.086 \\
(0.012)\end{array}$ & $\begin{array}{r}0.085 \\
(0.013)\end{array}$ & $\begin{array}{r}0.107 \\
(0.017)\end{array}$ & $\begin{array}{r}0.108 \\
(0.017)\end{array}$ & $\begin{array}{r}0.075 \\
(0.019)\end{array}$ & $\begin{array}{r}0.074 \\
(0.019)\end{array}$ \\
\hline Female & $\begin{array}{r}0.900 \\
(0.111)\end{array}$ & $\begin{array}{r}0.895 \\
(0.111)\end{array}$ & & & & \\
\hline Non-white & $\begin{array}{r}0.954 \\
(0.367)\end{array}$ & $\begin{array}{r}0.951 \\
(0.367)\end{array}$ & $\begin{array}{r}1.074 \\
(0.483)\end{array}$ & $\begin{array}{r}1.075 \\
(0.483)\end{array}$ & $\begin{array}{r}0.907 \\
(0.543)\end{array}$ & $\begin{array}{r}0.900 \\
(0.543)\end{array}$ \\
\hline O-Levels & $\begin{array}{r}-0.483 \\
(0.136)\end{array}$ & $\begin{array}{r}-0.480 \\
(0.136)\end{array}$ & $\begin{array}{r}-0.326 \\
(0.189)\end{array}$ & $\begin{array}{r}-0.328 \\
(0.189)\end{array}$ & $\begin{array}{r}-0.602 \\
(0.194)\end{array}$ & $\begin{array}{r}-0.599 \\
(0.194)\end{array}$ \\
\hline A-Levels & $\begin{array}{r}-0.344 \\
(0.166)\end{array}$ & $\begin{array}{r}-0.345 \\
(0.166)\end{array}$ & $\begin{array}{r}-0.337 \\
(0.207)\end{array}$ & $\begin{array}{r}-0.337 \\
(0.207)\end{array}$ & $\begin{array}{r}-0.337 \\
(0.267)\end{array}$ & $\begin{array}{r}-0.342 \\
(0.267)\end{array}$ \\
\hline HND, HNC or equiv & $\begin{array}{r}-0.563 \\
(0.221)\end{array}$ & $\begin{array}{r}-0.560 \\
(0.221)\end{array}$ & $\begin{array}{r}-0.479 \\
(0.290)\end{array}$ & $\begin{array}{r}-0.479 \\
(0.289)\end{array}$ & $\begin{array}{r}-0.592 \\
(0.333)\end{array}$ & $\begin{array}{r}-0.585 \\
(0.333)\end{array}$ \\
\hline Degree or above & $\begin{array}{r}-0.130 \\
(0.193)\end{array}$ & $\begin{array}{l}-0.127 \\
(0.193)\end{array}$ & $\begin{array}{r}0.219 \\
(0.248)\end{array}$ & $\begin{array}{r}0.218 \\
(0.248)\end{array}$ & $\begin{array}{r}-0.556 \\
(0.299)\end{array}$ & $\begin{array}{l}-0.551 \\
(0.299)\end{array}$ \\
\hline Unemployed & $\begin{array}{r}1.889 \\
(0.259)\end{array}$ & $\begin{array}{r}1.896 \\
(0.259)\end{array}$ & $\begin{array}{r}1.923 \\
(0.321)\end{array}$ & $\begin{array}{r}1.921 \\
(0.321)\end{array}$ & $\begin{array}{r}2.294 \\
(0.410)\end{array}$ & $\begin{array}{r}2.323 \\
(0.411)\end{array}$ \\
\hline Retired & $\begin{array}{r}-0.006 \\
(0.162)\end{array}$ & $\begin{array}{r}-0.008 \\
(0.162)\end{array}$ & $\begin{array}{r}0.396 \\
(0.224)\end{array}$ & $\begin{array}{r}0.395 \\
(0.224)\end{array}$ & $\begin{array}{r}-0.277 \\
(0.229)\end{array}$ & $\begin{array}{r}-0.291 \\
(0.230)\end{array}$ \\
\hline Out of Labour Force & $\begin{array}{r}1.590 \\
(0.168)\end{array}$ & $\begin{array}{r}1.592 \\
(0.168)\end{array}$ & $\begin{array}{r}4.657 \\
(0.408)\end{array}$ & $\begin{array}{r}4.657 \\
(0.408)\end{array}$ & $\begin{array}{r}0.711 \\
(0.172)\end{array}$ & $\begin{array}{r}0.711 \\
(0.172)\end{array}$ \\
\hline -squa & 0.047 & 0.047 & 0.067 & 0.067 & 0.028 & 0.02 \\
\hline bserva & 43824 & 43824 & 21001 & 21001 & 22823 & $2282 ?$ \\
\hline No. of individuals & 4878 & 4878 & 2416 & 2416 & 2462 & 246 \\
\hline
\end{tabular}

* Standard errors, here and in later tables, are given in parentheses. GHQ is measured on a 0-36 scale. All columns include year dummies

* Base individual is male, with no formal educational qualification, and currently in work. The 'divorced' variable here includes people who are separated. 
Table 3

Mean GHQ Stress Levels - A Lead and Lag Analysis around Transitions

\begin{tabular}{|c|c|c|c|}
\hline Time to event & $\frac{\text { Divorce }}{\text { transitions }}$ & $\frac{\text { Widowed }}{\text { transitions }}$ & $\underline{\text { Remain married }}$ \\
\hline $\mathrm{T}-2$ & 12.98 & 11.69 & 10.92 \\
\hline $\mathrm{T}-1$ & 14.25 & 12.27 & 10.96 \\
\hline $\mathrm{T}$ & 14.85 & 17.20 & 11.00 \\
\hline $\mathrm{T}+1$ & 12.42 & 13.07 & 11.06 \\
\hline $\mathrm{T}+2$ & 11.98 & 11.77 & 11.09 \\
\hline
\end{tabular}

- $\mathrm{T}$ denotes the first wave where we observe the individual reports their marriage has dissolved/ended due to being widowed. Mean stress levels for these individuals are then calculated for the years either side of the event.

- For those who remain married these are simply the lead and lag (mean) GHQ stress score.

\section{Figure 1 - Divorce and Mental Stress through Time}

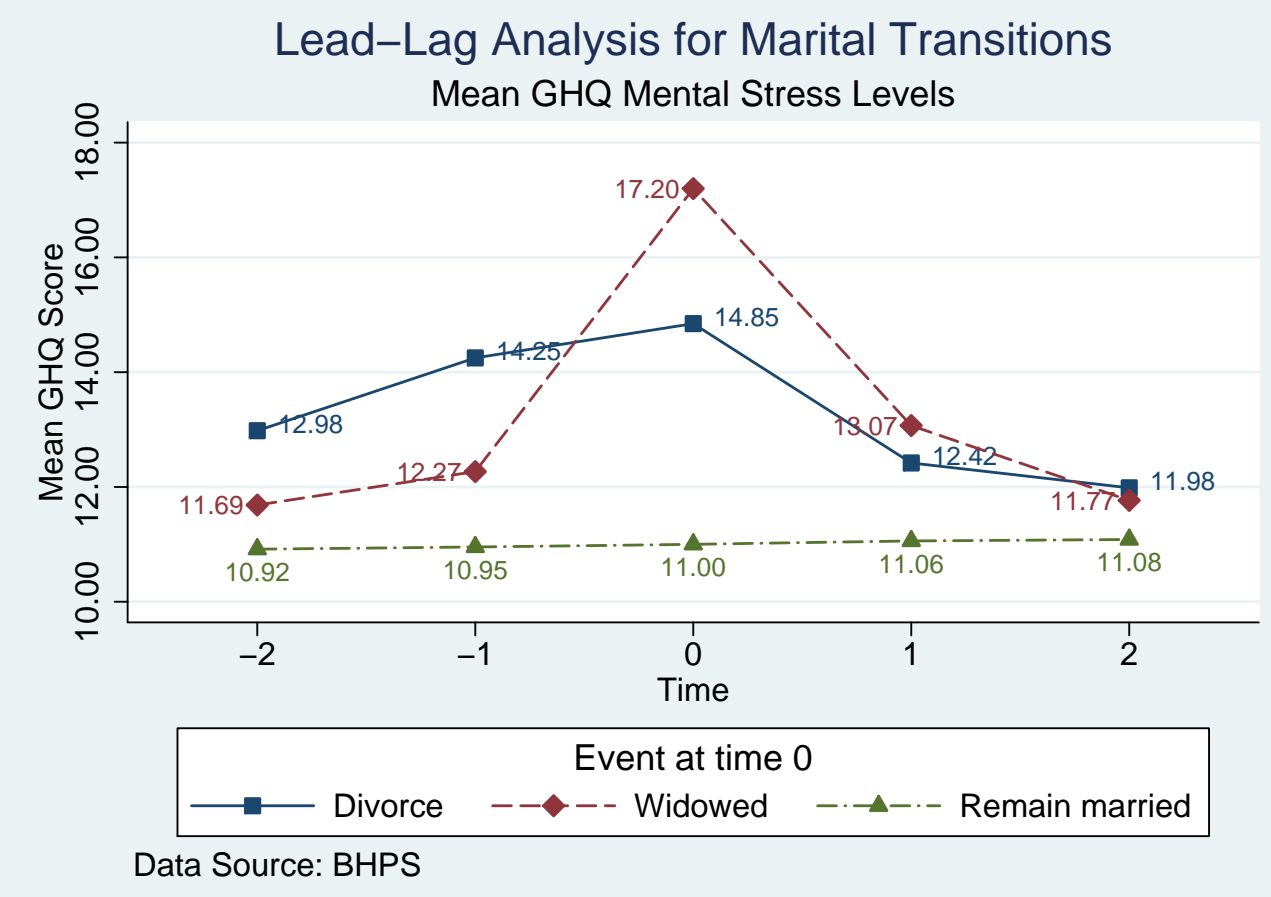


Table 4

Mean Changes in GHQ Stress Scores: Divorce and Bereavement

$\begin{array}{lll}\begin{array}{l}\text { Divorce } \\ \text { transitions }\end{array} & \underline{\text { Widowed }} & \underline{\text { Remain married }} \\ & \end{array}$

Change in GHQ

(T-1 to $\mathrm{T}$ )

$\begin{array}{ccc}0.577 & 4.763 & 0.113 \\ (0.419) & (0.419) & (0.026)\end{array}$

Difference vs. remain married

$$
0.464
$$

392

$-1.965$

$(0.422)$

0.826

$(0.364)$

4.651

(0.418)

241

32102

Change in GHQ

( $\mathrm{T}-1$ to $\mathrm{T}+1$ )

Difference vs.

remain married

$$
-2.136
$$

0.655

(0.364)

Number of

observations

Change in GHQ

( $\mathrm{T}-2$ to $\mathrm{T}+2$ )

$-0.974$

(0.451)

$-0.183$

(0.418)

0.248

(0.036)

Difference vs.

remain married

$$
-1.222
$$

$-0.431$

Number of observations

Notes

$$
270
$$

$$
175
$$$$
21121
$$

$\circ \mathrm{T}$ denotes the first wave where we observe the individual reports their marriage has dissolved/ended due to being widowed.

- For those who remain married these are simply the mean change in the GHQ stress score over the relevant period.

- Robust standard errors are in parentheses.

- The first row of statistics tests the null: $\mathrm{HO}$ - no change in GHQ wellbeing over the time period.

- The second row of statistics tests the null: $\mathrm{HO}$ - no difference in the change in GHQ wellbeing between the divorced/widowed and those who remain married. 
Figure 2 - Divorce, Wellbeing and Whether the Individual Remarries

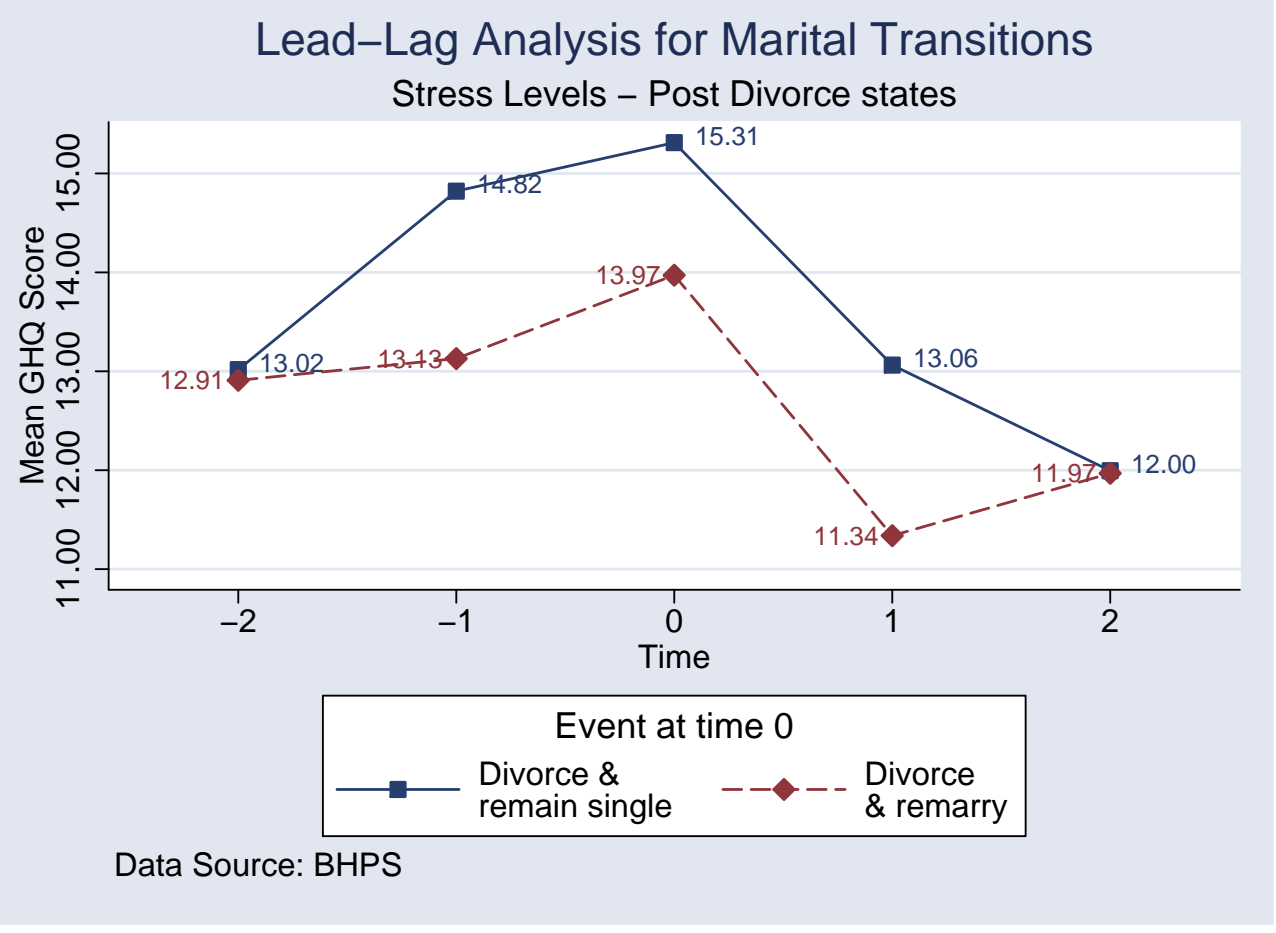

○ 255 remain single

○ 137 remarry 
Table 5

Mean Changes in GHQ Stress Scores: Divorce and Remarriage

$\begin{array}{lll}\frac{\text { Divorce and }}{\text { remain single }} & \frac{\text { Divorce and }}{\text { remarry }} & \begin{array}{c}\text { Difference: } \\ \text { remarry vs. single }\end{array}\end{array}$

Change in GHQ

( $\mathrm{T}-1$ to $\mathrm{T}$ )

$\begin{array}{ccc}0.416 & 0.876 & 0.460 \\ (0.535) & (0.672) & (0.858)\end{array}$

Difference vs.

remain married

0.303

0.763

(0.534)

(0.670)

Number of

observations

255

137

Change in GHQ

(T-1 to $\mathrm{T}+1)$

$-2.093$

$-1.756$

$(0.595)$

0.337

$(0.576)$

(0.828)

Difference vs.

remain married

$-2.263$

(0.575)

$-1.927$

(0.594)

Number of

observations

216

131

Change in GHQ

(T-2 to $\mathrm{T}+2$ )

$-1.036$

$-0.876$

0.160

(0.595)

(0.688)

(0.909)

Difference vs.

remain married

$-1.284$

(0.594)

Number of

observations

Notes

165
$-1.124$

(0.686)

105

- $\mathrm{T}$ denotes the first wave where we observe the individual reports their marriage has dissolved/ended due to being widowed.

- For those who remain married these are simply the mean change in the GHQ stress score over the relevant period.

- Robust standard errors are in parentheses.

- The first row of statistics tests the null: $\mathrm{HO}$ - no change in GHQ wellbeing over the time period.

- The second row of statistics tests the null: $\mathrm{HO}$ - no difference in the change in GHQ wellbeing between the divorced/widowed and those who remain married. 
Figure 3 - The Impact of Divorce by Gender

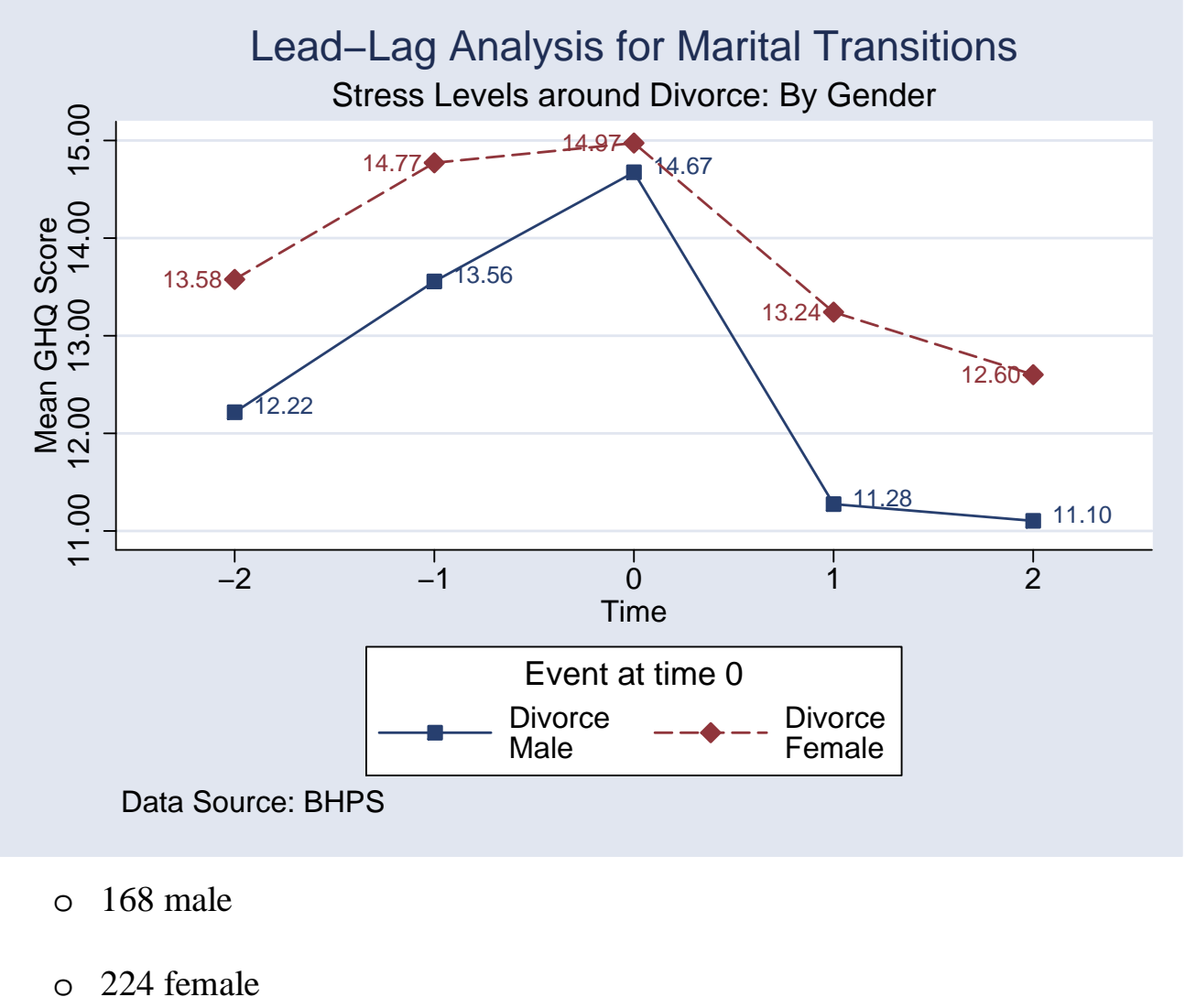


Figure 4 - The Impact of Widowhood by Gender

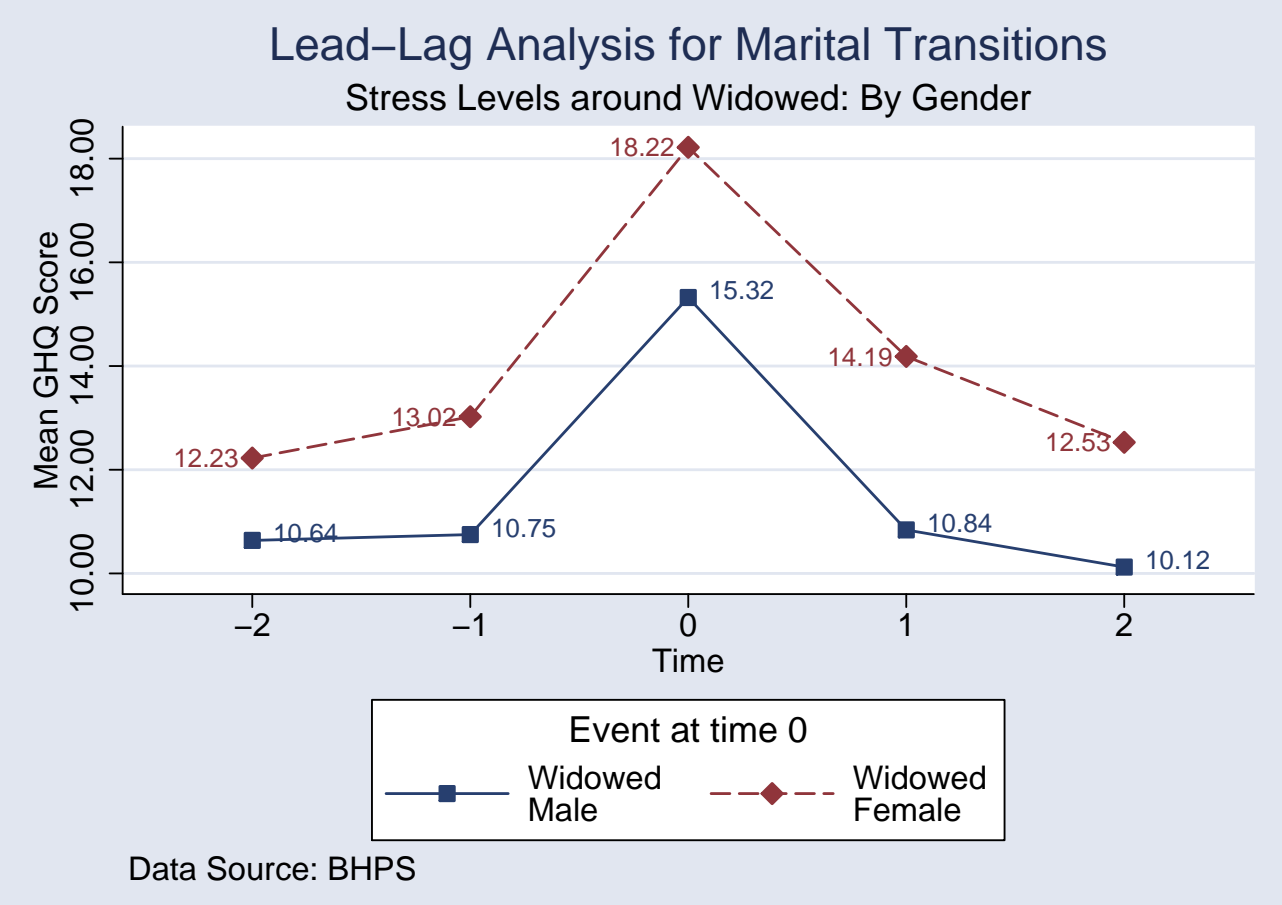

○ 83 males

- 158 females 
Table 6

Mean Changes in GHQ Stress Scores: By Gender

Difference:

Change in GHQ

(T-1 to $\mathrm{T}$ )

Divorce-Male Divorce-Female Female vs. Male

$\begin{array}{ccc}0.958 & 0.290 & 0.668 \\ (0.677) & (0.530) & (0.860)\end{array}$

Difference vs.

remain married

0.860

(0.676)

0.164

$(0.531)$

Number of

observations

Change in GHQ

( $\mathrm{T}-1$ to $\mathrm{T}+1)$

$-2.541$

(0.602)

$-1.547$

(0.584)

0.994

(0.838)

Difference vs.

remain married

$-2.676$

(0.601)

$-1.753$

(0.584)

Number of

observations

Change in GHQ

( $\mathrm{T}-2$ to $\mathrm{T}+2)$

$-1.018$

(0.618)

$-0.943$

(0.636)

0.075

$(0.887)$

Difference vs.

remain married

$-1.213$

(0.617)

Number of

observations

Notes

- $\mathrm{T}$ denotes the first wave where we observe the individual reports their marriage has dissolved/ended due to being widowed.

- For those who remain married these are simply the mean change in the GHQ stress score over the relevant period.

- Robust standard errors are in parentheses.

- The first row of statistics tests the null: $\mathrm{HO}$ - no change in GHQ wellbeing over the time period.

- The second row of statistics tests the null: $\mathrm{HO}$ - no difference in the change in GHQ wellbeing between the divorced/widowed and those who remain married. 
Figure 5 - Divorce and Whether the Individual has Children in the Household in the Year Prior to Divorce

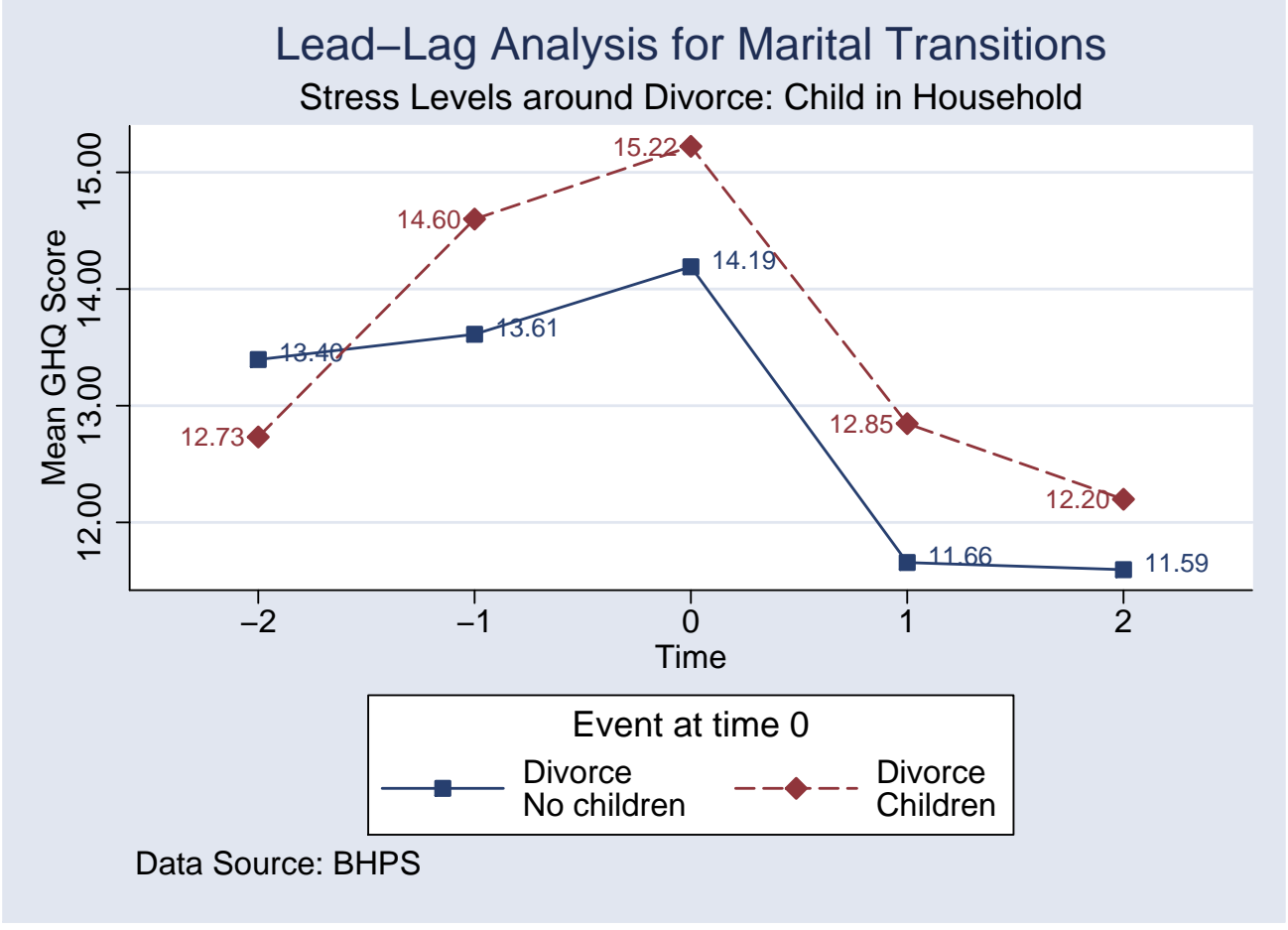

- 223 with children

○ 124 without children 
Table 7

Mean Changes in GHQ Stress Scores: Those With and Without Children

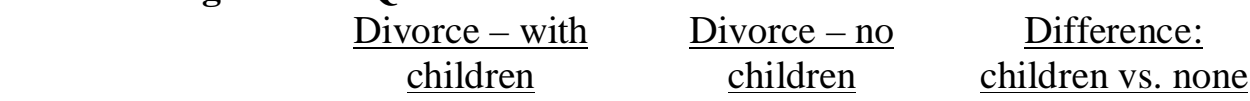

Change in GHQ

( $\mathrm{T}-1$ to $\mathrm{T}$ )

$\begin{array}{ccc}0.520 & 0.676 & -0.156 \\ (0.532) & (0.682) & (0.865)\end{array}$

Difference vs. remain married

0.431

$(0.533)$

Number of

observations

Change in GHQ

( $\mathrm{T}-1$ to $\mathrm{T}+1)$

$-1.865$

$(0.546)$

(0.661)

0.548

(0.681)

142

Difference vs.

remain married

$-1.992$

(0.547)

$-2.347$

(0.659)

Number of

observations

223

124

Change in GHQ

( $\mathrm{T}-2$ to $\mathrm{T}+2$ )

$-0.433$

(0.555)

$-1.909$

(0.763)

1.476

(0.943)

Difference vs.

remain married

$-0.719$

(0.557)

171
0.280

(0.857)
Number of observations

Notes

- $\mathrm{T}$ denotes the first wave where we observe the individual reports their marriage has dissolved/ended due to being widowed.

- For those who remain married these are simply the mean change in the GHQ stress score over the relevant period.

- Robust standard errors are in parentheses.

- The first row of statistics tests the null: $\mathrm{HO}$ - no change in GHQ wellbeing over the time period.

The second row of statistics tests the null: $\mathrm{HO}$ - no difference in the change in GHQ wellbeing between the divorced/widowed and those who remain married. 
Figure 6 - GHQ Stress Scores inside Marriages

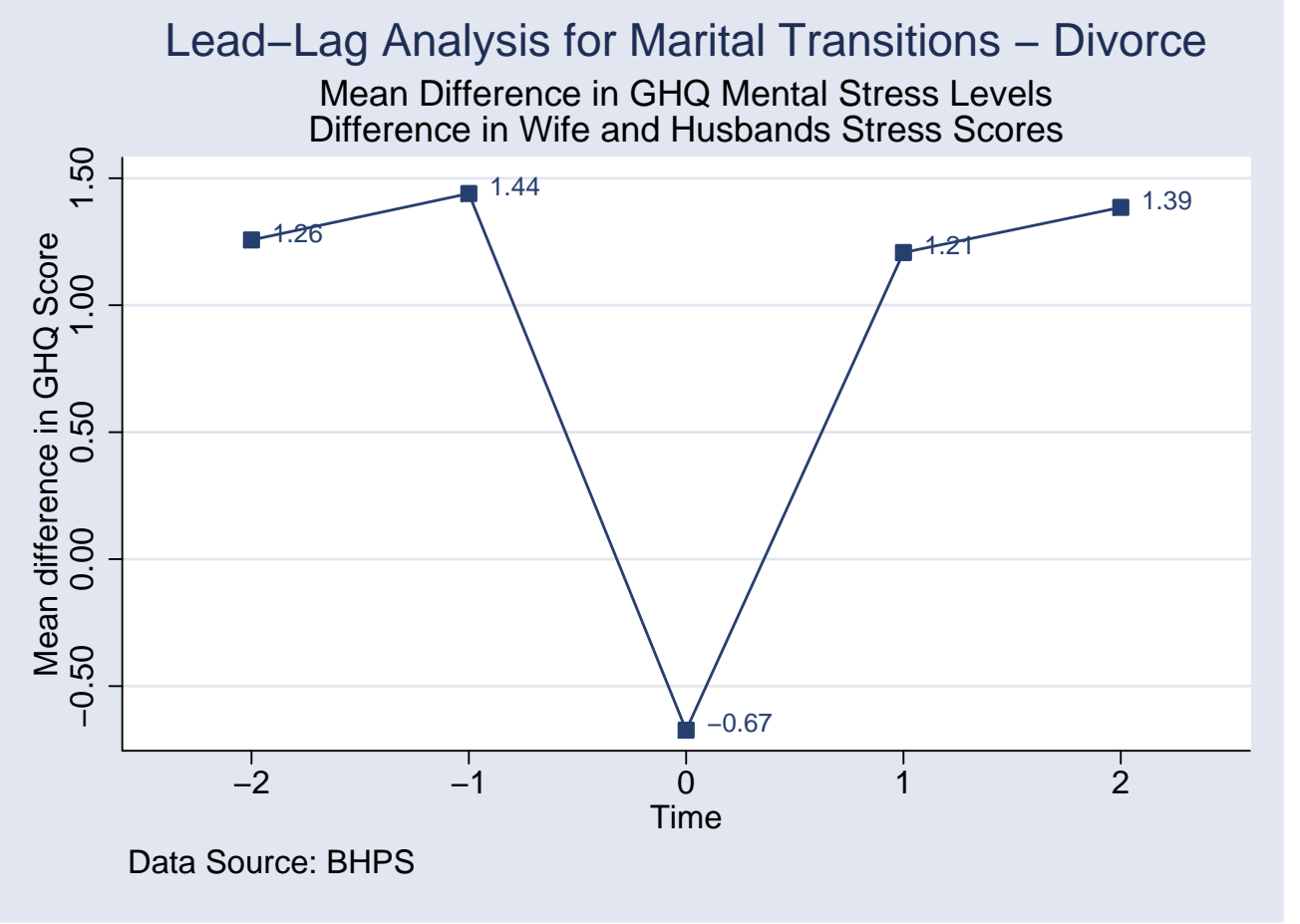

- Approximately 147 marital pairs observed at time of divorce (greater numbers before and fewer afterwards) 


\section{Figure 7}

\section{Divorce and Life Satisfaction Through Time}

1996-2000

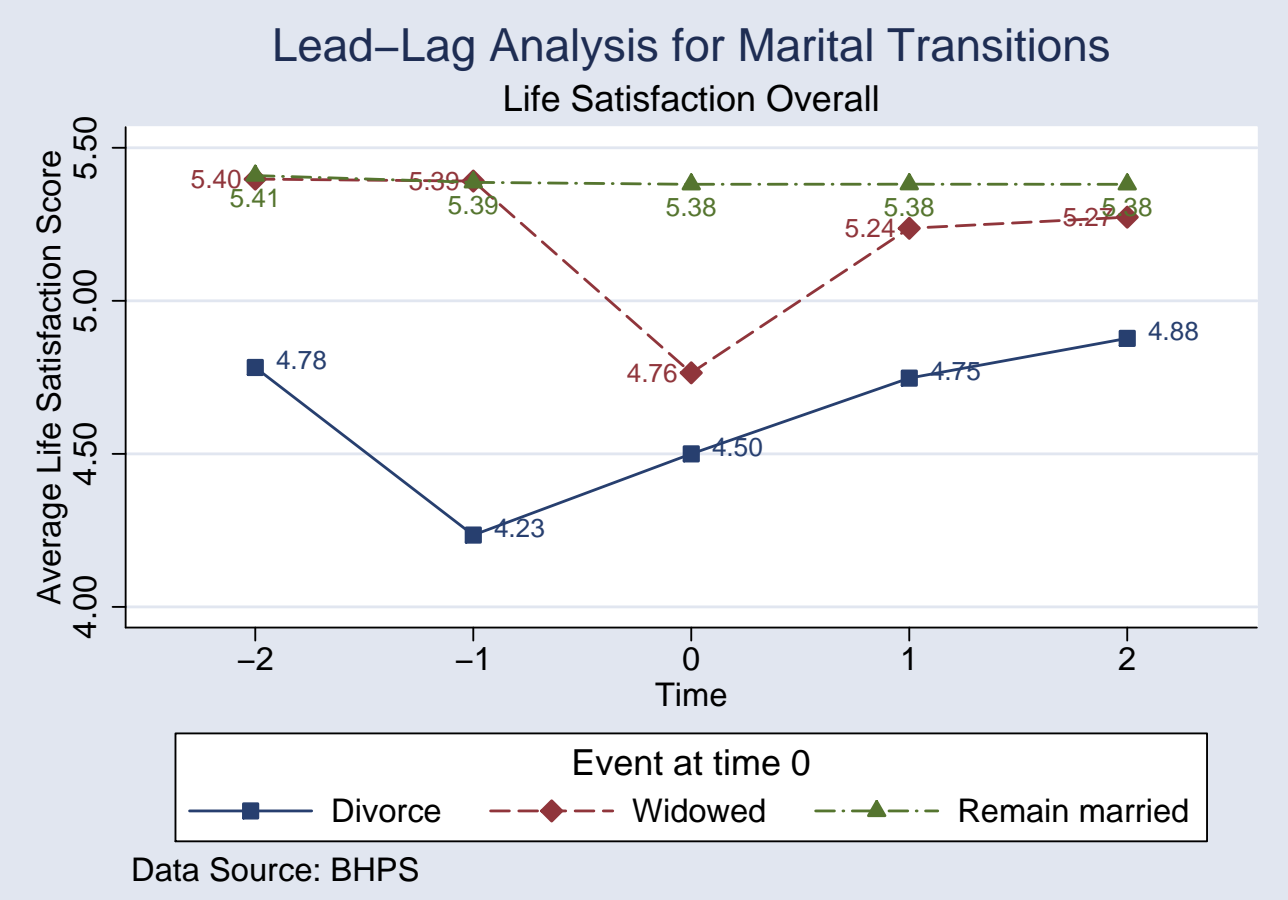

The sample here is shorter than in earlier graphs, because data on life satisfaction are not available in all years of the BHPS. 
Table 8

Mean Changes in Life Satisfaction

\begin{tabular}{|c|c|c|c|}
\hline & $\frac{\text { Divorce }}{\text { transitions }}$ & $\frac{\text { Widowed }}{\text { transitions }}$ & Remain married \\
\hline $\begin{array}{l}\text { Change in life } \\
\text { satisfaction (T-1 } \\
\text { to } \mathrm{T} \text { ) }\end{array}$ & 0.373 & -0.500 & -0.030 \\
\hline & $(0.136)$ & $(0.166)$ & $(0.010)$ \\
\hline $\begin{array}{l}\text { Difference vs. } \\
\text { remain married }\end{array}$ & 0.404 & -0.470 & - \\
\hline & $(0.136)$ & $(0.166)$ & - \\
\hline $\begin{array}{l}\text { Number of } \\
\text { observations }\end{array}$ & 142 & 92 & 12127 \\
\hline $\begin{array}{l}\text { Change in life } \\
\text { satisfaction }(\mathrm{T}-1 \\
\text { to } \mathrm{T}+1)\end{array}$ & 0.543 & -0.012 & -0.048 \\
\hline & $(0.160)$ & $(0.162)$ & $(0.011)$ \\
\hline $\begin{array}{l}\text { Difference vs. } \\
\text { remain married }\end{array}$ & 0.591 & 0.035 & - \\
\hline & $(0.160)$ & $(0.162)$ & - \\
\hline $\begin{array}{l}\text { Number of } \\
\text { observations }\end{array}$ & 116 & 82 & 8945 \\
\hline $\begin{array}{l}\text { Change in life } \\
\text { satisfaction }(\mathrm{T}-2 \\
\text { to } \mathrm{T}+2)\end{array}$ & 0.048 & 0.345 & -0.121 \\
\hline & $(0.236)$ & $(0.396)$ & $(0.022)$ \\
\hline $\begin{array}{l}\text { Difference vs. } \\
\text { remain married }\end{array}$ & 0.169 & 0.469 & - \\
\hline & $(0.234)$ & $(0.388)$ & - \\
\hline $\begin{array}{l}\text { Number of } \\
\text { observations }\end{array}$ & 42 & 23 & 2889 \\
\hline
\end{tabular}

Notes

- $\mathrm{T}$ denotes the first wave where we observe the individual reports their marriage has dissolved/ended due to being widowed.

- For those who remain married these are simply the mean change in the life satisfaction score over the relevant period.

- Robust standard errors are in parentheses.

- The first row of statistics tests the null: $\mathrm{H} 0$ - no change in life-satisfaction over the time period.

- The second row of statistics tests the null: $\mathrm{H0}$ - no difference in the change in life-satisfaction between the divorced/widowed and those who remain married. 